\title{
Seasonal changes in oestrogen receptor affinity in the domestic rabbit, Oryctolagus cuniculus*
}

\author{
J. E. Stern† and G. L. Vaughan \\ Zoology Department, University of Tennessee at Knoxville, Knoxville, Tennessee 37916, U.S.A.
}

\begin{abstract}
Summary. Over the course of 1 year the $K_{\mathrm{a}}$ value of uterine oestrogen receptor for oestradiol varied 10 -fold from a low of $0.259 \pm 0.065 \times 10^{9} \mathrm{M}^{-1}$ in early spring to $2.21 \pm 0.21 \times 10^{9} \mathrm{M}^{-1}$ in fall. There were no significant changes in receptor number. In addition, administration of oestradiol or progesterone to ovariectomized rabbits resulted in significant reductions in measureable oestrogen receptor affinity. Although these variations in oestrogen receptor $K_{\mathrm{a}}$ values parallel reproductive success in the domestic rabbit, no causal relationship has been established.
\end{abstract}

\section{Introduction}

Seasonal changes in reproduction, pronounced in wild rabbits (Sadleir, 1969; Conaway et al., 1974), have been reduced, but not eliminated, in domestic stocks which are productive throughout the year. During the spring months, females accept males readily and copulations, in most cases, produce sizable litters. In fall and winter months even domestic animals are less productive (Reed, 1979). Rabbits, induced ovulators with a short gestation period (about 31 days), have been used extensively in investigations of implantations, pregnancy, and parturition, but little attention has been given to the phenomenon of seasonality. This is largely because a biochemical basis and confirmation of the observed seasonal variation has not been available. In the course of studying oestrogen receptor properties of rabbit endometrium and myometrium (Stern \& Vaughan, 1978, $1979)$ we have observed a seasonal shift in oestrogen receptor affinity $\left(K_{\mathrm{a}}\right)$ which is accompanied by a difference in fecundity between the spring and fall months.

\section{Materials and Methods}

New Zealand White rabbits, weighing about 2.7 and $4.1 \mathrm{~kg}$ and at least 6 months of age, were obtained from Graves Rabbitry of Knoxville, Tennessee, where they had been exposed to prevailing seasonal conditions. These animals were subsequently housed in an authorized animal facility and used within 2 weeks of purchase. Mature, virgin females were mated with males of proven fertility and killed at 12:00 h during the first week of pregnancy. Uterine tissue was removed, freed of connecting fat, placed on ice, and flushed with cold TEM buffer (40 mM-Tris, 1.5 mM-EDTA, $15 \mathrm{~mm}-\mathrm{monothioglycerol,} 50 \mathrm{mM}-\mathrm{KC} 1$ and $10 \%(\mathrm{v} / \mathrm{v})$ glycerol). since $K_{\mathrm{a}}$ values for oestrogen receptor were reduced by 40 to $80 \%$ in the few frozen samples measured, only fresh tissue was used in this study. Endometrium was separated from myometrium by gentle scraping. Receptor properties in the two tissues were measured separately. A high speed centrifugation of tissue homogenates $(100000 \mathrm{~g} \times 10 \mathrm{~min})$ produced a particle-free cytosol in TEM, samples of which were incubated $\left(0^{\circ} \mathrm{C}, 16 \mathrm{~h}\right)$ with various concentrations of $\left[{ }^{3} \mathrm{H}\right]$ oestradiol- $17 \beta$ (serial concentrations covering the range $\left(10^{-10}\right.$ to $\left.10^{-8} \mathrm{M}\right)$, or with $\left[{ }^{3} \mathrm{H}\right.$ ]oestradiol-17 $\beta$ and diethylstilboestrol in 100 -fold excess as competitor. Receptorbound and free hormone were separated by an hydroxylapatite (HAP) batch separation procedure (Pavlik \& Coulson, 1976) where the hormone-receptor complex binds to HAP. $\left[{ }^{3} \mathrm{H}\right]$ Oestradiol was routinely purified on an $\mathrm{LH}_{20}$ minicolumn eluted with benzene:methanol $(90: 10, \mathrm{v} / \mathrm{v})(\mathrm{Wu} \&$ Lundy, 1971). Data were analysed by the method of Scatchard (1949) to derive values for receptor titre and oestradiol affinity.

*Reprint requests to Dr G. L. Vaughan

†Present address: Dartmouth-Hitchcock Medical Center, Hanover, New Hampshire 03756, U.S.A. 
To evaluate the effect for oestradiol and progesterone on uterine oestrogen receptors animals were ovariectomized and treated with hormone. For surgery, the rabbits were injected with fentamyl and droperidol (Innovar-Vet: PittmanMoore), at a concentration of $0.3 \mathrm{ml}$ per $\mathrm{kg}$ body weight $10 \mathrm{~min}$ before operation. Immediately before surgery, $0.2 \mathrm{ml}$ $(10 \mathrm{mg}$ ) pentobarbitone sodium was administered. A midventral incision was made and a double thickness of 00 silk was pulled through the fatty tissue on either side of the mesentery and tied securely to restrict the blood vessels to the ovary. The ovary was then excised. Each animal was given 300 units of antibiotic containing benzathine penicillin and procaine penicillin $\mathrm{G}$, and allowed to recover from anaesthesia under a heat lamp. A cardboard neck collar was attached to each animal to prevent biting of the stitches and removal of the suture.

Oestradiol-17 $(100 \mu \mathrm{g} / \mathrm{ml})$ and progesterone $(3 \mathrm{mg} / \mathrm{ml})$ were dissolved in unrefined sesame oil previously filtered through Fisher filter paper. Gentle heating and stirring were required to fully dissolve the steroid in the oil. Oil for control groups was treated in the same manner. Subcutaneous injections were given twice daily in the loose skin behind the neck using a 20-gauge needle. The dose was calculated on the basis of body weight $(1 \mathrm{ml} / \mathrm{kg}) \mathrm{giving}$ a concentration of $100 \mu \mathrm{g} / \mathrm{kg} /$ day for oestradiol and $3 \mathrm{mg} / \mathrm{kg} /$ day for progesterone. Half of this dose was given at $10: 00 \mathrm{~h}$ and half at 17:00 $\mathrm{h}$ on each day of injection. Animals were injected on Days 2-5 after ovariectomy and killed at 12:00 h on Day 6. Tissues were treated as described above.

\section{Results}

Seasonal changes in oestrogen receptor $K_{\mathrm{a}}$ value are shown in Fig. 1. Receptor $K_{\mathrm{a}}$ value was lowest in February, increased through early summer and remained at constant high levels through late summer and fall. Both endometrial and myometrial values are included in the figure as no significant difference in the seasonal variation was seen between the two tissues.

Figure 2 shows representative Scatchard plots for animals in the spring and fall months. Data are from myometrial samples of 1-day pregnant rabbits assayed in March or November. There was a significant difference between the affinity of binding in the two seasons $\left(0.73 \times 10^{8} \mathrm{M}^{-1}\right.$ and $2.36 \times 10^{9} \mathrm{M}^{-1}$ respectively). No difference was observed, however, in total binding ( $0.297 \mathrm{vs}$ $0.222 \mathrm{fmol} / \mu \mathrm{g}$ protein). Both lines show good correlation coefficients $(0.941$ and 0.987$)$ and the change in affinity did not appear to be related to an increase in non-specific binding.

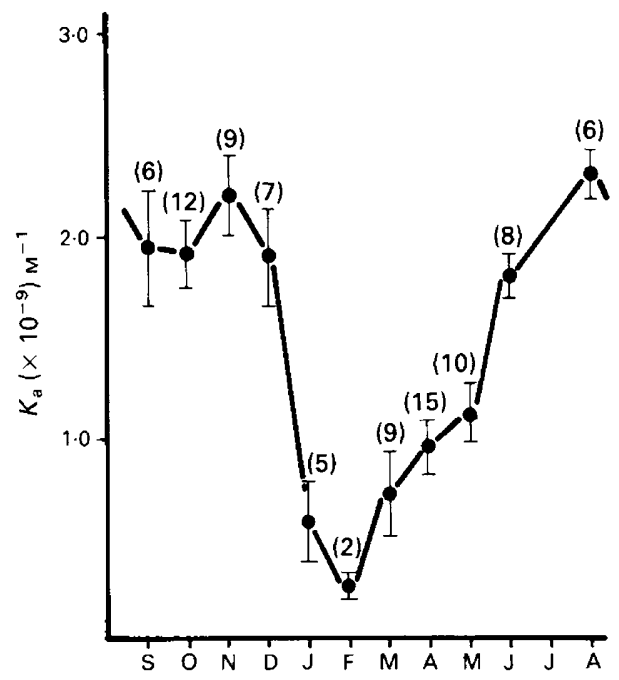

Fig. 1. Seasonal changes in oestrogen receptor affinity constant $\left(K_{\mathrm{a}}\right)$. Receptor $K_{\mathrm{a}}$ values were derived from the slope of the line of the bound versus bound over free plot of data from samples assayed over a 16-month period. The values December through April represent a composite of data from two separate years. Numbers of individuals are shown for each point. Vertical bars are s.e.m. (except for the February point in which the vertical bars represent the range of the values). 


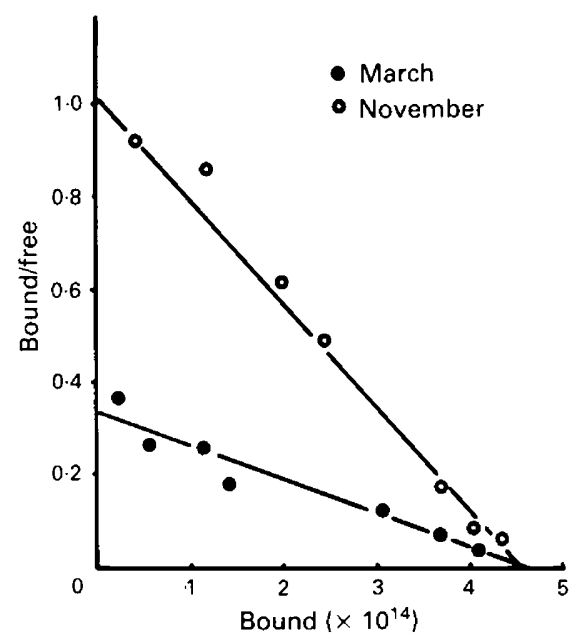

Fig. 2. Scatchard plot analysis of binding parameters of oestrogen receptors in the myometrium of Day-1 pregnant rabbits in the spring and fall. Values represent duplicate points from which competition from diethylstilboestrol has been subtracted.

Table 1. Comparison of spring and fall titre and $K_{\mathrm{a}}$ value from 1-day pregnant rabbits*

\begin{tabular}{lllcc}
\hline & & & \multicolumn{2}{c}{ Titre } \\
\cline { 4 - 5 } Tissue & Season & $K_{\mathrm{a}}\left(\times 10^{-9}\right) \mathrm{M}^{-1}$ & $\mathrm{fmol} / \mu \mathrm{g} D N A$ & $\mathrm{fmol} / \mu \mathrm{g}$ protein \\
\hline Endometrium & Fall & $2 \cdot 23 \pm 0.33$ & $1.27 \pm 0.30$ & $0.362 \pm 0.030$ \\
& Spring & $0.77 \pm 0.51^{*}$ & $1.70 \pm 0.62$ & $0.352 \pm 0.040$ \\
Myometrium & Fall & $2.43 \pm 0.42$ & $2.74 \pm 0.67$ & $0.265 \pm 0.044$ \\
& Spring & $0.40 \pm 0.17^{* *}$ & $3.66 \pm 0.37$ & $0.317 \pm 0.010$ \\
\hline
\end{tabular}

Each value represents the mean \pm s.e.m. from 3 animals.

${ }^{*} P<0.05 ;{ }^{* *} P<0.01$ compared with $K_{\mathrm{a}}$ values for fall.

Table 2. Oestrogen receptor concentration after in-vivo hormone treatment

\begin{tabular}{|c|c|c|c|c|c|c|}
\hline \multirow[b]{2}{*}{ Treatment } & \multicolumn{2}{|c|}{$\mathrm{fmol} / \mu \mathrm{g}$ protein } & \multicolumn{2}{|c|}{$\mathrm{fmol} / \mu \mathrm{g}$ DNA } & \multicolumn{2}{|c|}{ Total receptor (pmol) } \\
\hline & Endometrium & Myometrium & Endometrium & Myometrium & Endometrium & Myometrium \\
\hline Oil & $0.624 \pm 0.091$ & $0.390 \pm 0.027$ & $1.21 \pm 0.53$ & $2 \cdot 53 \pm 0 \cdot 1$ & & $25 \cdot 8 \pm 2 \cdot 1$ \\
\hline Oestradiol & $0.125 \pm 0.035$ & $0.130 \pm 0.084^{*}$ & $0.77 \pm 0.34$ & $2.63 \pm 1.73$ & $6 \cdot 2 \pm 0 \cdot 2^{* *}$ & $37 \cdot 7 \pm 5 \cdot 4$ \\
\hline Progesterone & $0.450 \pm 0.095$ & $0.222 \pm 0.056^{*}$ & $2.78 \pm 0.74$ & $5.31 \pm 1.64$ & $34.8 \pm 10.6^{*}$ & $25 \cdot 8 \pm 8 \cdot 1$ \\
\hline
\end{tabular}

Values are the mean \pm s.e.m. for 3 animals.

${ }^{*} P<0.05 ;{ }^{* *} P<0.01$ compared to value for oil-treated animals.

Table 1 compares the titres and affinity constants of oestrogen receptors for one group of fall and one group of spring animals. Although the $K_{\mathrm{a}}$ value of the receptor was depressed during the spring in both tissues, the titres of receptors were not significantly different from spring to winter. Annual changes in affinity were not accompanied by changes in receptor titre.

Figure 3 shows the influence of in-vivo administration of oestradiol and progesterone on endometrial and myometrial oestrogen receptor affinity. Both hormones significantly reduced the $K_{\mathrm{a}}$ value in myometrium $(P<0.05$ for progesterone and $P<0.01$ for oestradiol) while only oestradiol 


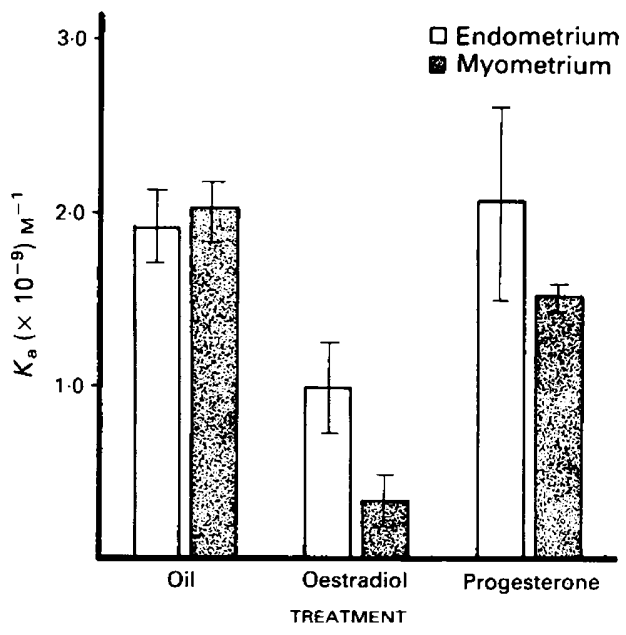

Fig. 3. Influence of in-vivo oestrogen or progesterone on oestrogen receptor affinity constant $\left(K_{\mathrm{a}}\right)$. Oestrogen $(100 \mu \mathrm{g} / \mathrm{kg} / \mathrm{day})$ or progesterone $(3 \mathrm{mg} / \mathrm{kg} /$ day $)$ was administered to ovariectomized animals for 4 days. There were 3 samples per treatment group.

significantly depressed endometrial receptor affinity $(P<0.05)$. Both hormones decreased receptor titre when normalized to $\mu \mathrm{g}$ protein, but an apparent increase in receptor titre occurred in response to progesterone when reported as a function of DNA (Table 2).

\section{Discussion}

Domestic rabbits of the species Oryctolagus cuniculus are commonly assumed to display no seasonal breeding behaviour. Seasonal changes in litter size, percentage pregnancies, and properties of the reproductive tract, have, however, been reported for wild rabbits. Wild rabbits produce more offspring during mild spring months than during fall or late winter months (Elder \& Finerty, 1943; Marsden \& Conaway, 1963; Sadleir, 1969).

$K_{\mathrm{a}}$ values, in this study, were lowest in February, increased through June, and remained high throughout the late summer and fall. Tennessee has four distinct seasons, with the summer months of July and August being particularly hog $\left(26-32^{\circ} \mathrm{C}\right)$, the winter mild, and spring weather beginning late February and mid-March. The period of low receptor $K_{\mathrm{a}}$ value, in our animals, matched the productive spring season. The increase in $K_{\mathrm{a}}$ value between February and June correlated with increasing daylength and increasing temperatures.

Batra \& Kallstrand (1979) have demonstrated that mean oestrogen concentrations of oestrous female rabbits are lower in September than in January. Although we were working with pregnant animals, these data correlate well with Fig. 1 and with our observation (Fig. 3) that oestrogen administered to ovariectomized animals reduced cytoplasmic oestrogen receptor $K_{\mathrm{a}}$ value. Critical levels of oestrogen may be needed for normal development of corpora lutea during early pregnancy in the rabbit (Miller \& Keyes, 1975). High levels of oestrogen are, however, inhibitory to uterine development in this progesterone-dependent animal (Hilliard \& Eaton, 1971; Kwun \& Emmens, 1974). Perhaps, when oestrogen levels are higher in spring, corpus luteum development in early pregnancy is facilitated while lower uterine receptor $K_{\mathrm{a}}$ values protect the uterus, enabling implantation to proceed.

Several studies have reported progesterone-sensitive variations in uterine oestrogen receptor titre during pregnancy in the rabbit (Lee et al., 1971; Jacobson et al., 1972; Quirk \& Currie, 1984). 
Evans et al. (1980) and Okulicz et al. (1981) describe a progesterone-controlled regulatory factor for oestrogen receptor in the hamster. Boyd \& Spelsberg (1980) report seasonal rhythms in oestrogen and progesterone receptor translation and nuclear binding in the chick oviduct. They suggest that the variation in progesterone receptor is a function of a rhythm of oestrogen action. None of these studies reported a significant variation in oestrogen receptor $K_{\mathrm{a}}$ values. This may, when oestrogen receptor $K_{\mathrm{a}}$ value was examined, be a reflection of the fact that tissues were usually frozen before assay.

Changes in oestrogen receptor $K_{\mathrm{a}}$ values need not be causally related to seasonal changes in reproductive success. It is possible that oestrogen receptor $K_{\mathrm{a}}$ value and reproductive behaviour were both responding to an additional seasonally-modified agent. Photoperiod influences attainment of puberty, length of oestrous cycles, and duration of pregnancies in many mammalian species. These functions reflect LH and FSH concentration and involve the pineal gland (Hoffman, 1973). It is possible that fluctuations in pituitary or pineal output could be influential in producing the observed seasonal variation.

Functions for shifts in receptor $K_{\mathrm{a}}$ values are not known. Nevertheless, changes in $K_{\mathrm{a}}$ value of the progesterone receptor have been previously reported for rabbits (Rao et al., 1973; Davies et al., 1974). Our demonstration that oestrogen and progesterone administered in vivo can produce such changes in rabbit oestrogen receptors suggest that modifications in receptor affinity may have a specific function in this species. Seasonal changes in receptor may result from seasonal variations in the levels of reproductive hormone and should not be ignored in studies of reproductive physiology.

\section{References}

Batra, S. \& Kallstrand, K. (1979) Are there cyclic variations in oestradiol secretion in the non-pregnant rabbit? Experientia 35, 699-701.

Boyd, P.A. \& Spelsberg, T.C. (1980) Seasonal changes in the molecular species and nuclear binding of the chick oviduct progesterone receptor. Biochemistry N.Y. 95, 3705-3713.

Conaway, C.H., Sadler, K.C. \& Hazelwood, D.H. (1974) Geographic variation in litter size and onset of breeding in cottontails. J. Wildl. Mgmt 38, 473-481.

Davies, I.J., Challis, J.R.G. \& Ryan, K.J. (1974) Progesterone receptors in the myometrium of pregnant rabbits. Endocrinology 95, 165-173.

Elder, W.H. \& Finerty, J.C. (1943) Gonadotrophic activity of the pituitary gland in relation to the seasonal sexual cycle of the cottontail rabbit (Sylvilagus floridanus mearnsi). Anat. Rec. 85, 1-15.

Evans, R.W., Chen, T.J., Hendry W.J., III \& Leavitt, W.W. (1980) Progesterone regulation of oestrogen receptor in the hamster uterus during the estrous cycle. Endocrinology 107, 383-390.

Hilliard, J. \& Eaton, L.W.M. (1971) Estradiol-17ß, progesterone and 20-hydroxypregn-4-en-3-one in rabbit ovarian venous plasma. II from mating through implantation. Endocrinology 89, 522-527.

Hoffman, J.C. (1973) The influence of photoperiod on reproductive functions in female mammals. In Handbook of Physiology Vol. 7 (II) part I, pp. 57-77. Eds R. O. Greep \& E. B. Astwood. Am. Physiol. Soc., Washington, D.C.

Jacobson, H.I., Keyes, P.L. \& Bullock, D.W. (1972) Regulation of uterine oestrogen receptor by luteal progesterone in the pseudopregnant rabbit. Biol. Reprod. 7, 108, Abstr.
Kwun, J.K. \& Emmens, C.W. (1974) Hormonal requirements for implantation and pregnancy in the ovariectomized rabbit. Aust. J. biol. Sci. 27, 275-283.

Lee, C., Keyes, P.L. \& Jacobson, H.I. (1971) Estrogen receptor in the rabbit corpus luteum. Science, N.Y. 173, 1032-1033.

Marsden, H.M. \& Conaway, C.H. (1963) Behavior and the reproductive cycle in the cottontail. J. Wildl. Mgmt 27, 161-170.

Miller, J.B. \& Keyes, P.L. (1975) Progesterone synthesis in developing rabbit corpora lutea in the absence of follicular oestrogens. Endocrinology 97, 83-90.

Okulicz, W.C., Macdonald, R.G. \& Leavitt, W.W. (1981) Progesterone-induced oestrogen receptor-regulatory factor in hamster uterine nuclei: preliminary characterization in a cell-free system. Endocrinology 109, 2273-2275.

Pavlik, E.J. \& Coulson, P.B. (1976) Hydroxylapatite batch assay for oestrogen receptors: increased sensitivity over present receptor assays. J. Steroid Biochem. 7, $357-368$

Quirk, S.M. \& Currie, W.B. (1984) Uterine steroid receptor changes associated with progesterone withdrawal during pregnancy and pseudopregnancy in rabbits. Endocrinology 114, 182-191

Rao, B.R., Wiest, W.G. \& Allen, W.M. (1973) Progesterone "receptor" in rabbit uterus I. Characterization and estradiol-17 $\beta$ augmentation. Endocrinology 92. 1229-1241.

Reed, T.E. (1979) Function of the female reproductive tract. In Domestic Rabbits Vol. March/April, pp. 8-10. American Rabbit Breeders Association Official Publication, Bloomington, II.

Sadleir, R.M.F.S. (1969) The Ecology of Reproduction in 
Wild and Domestic Mammals. Methuen and Co. Ltd, London.

Scatchard, G. (1949) The attractions of proteins for small molecules and ions. Ann. N.Y. Acad. Sci. 51, 660-672.

Stern, J.E. \& Vaughan, G.L. (1978) Differences in endometrial and myometrial cytosolic oestrogen receptor in the rabbit. J. Cell Biol. 79, 172a, Abstr.
Stern, J.E. \& Vaughan, G.L. (1979) Seasonal variation in rabbit oestrogen receptor $\mathrm{Ka}$ : modification of affinity by oestrogen and progesterone in vivo. J. Cell Biol.83, 249 a.

Wu, C.H. \& Lundy, L.E. (1971) Radioimmunoassay of plasma oestrogens. Steroids 18, 91-111.

Received 13 March 1986 